\title{
PROSPEK IMPLEMENTASI SAK ETAP BERBASIS KUALITAS LAPORAN KEUANGAN UMKM
}

\author{
Barkah Susanto \\ Nur Laila Yuliani \\ Universitas Muhammadiyah Magelang \\ Imajidayasa@yahoo.com
}

\begin{abstract}
The purpose of this study is to evidence the factors that influence the perception of the importance of entrepreneurs related to accounting and financial reporting efforts and understanding SME entrepreneurs as well as proving the influence of the quality of financial reports to the growing number of bank credit received by SMEs in the City and County of ex-Kedu residency. Plan activities will include sampling with purposive sampling, data collection, and then tested by regression analysis testing tool. The results of the data analysis can be concluded that the respondent SMEs in this study have the perception that the accounting and financial reporting is important in the growth and development of its business. Latest education has positive influence on the perception of respondents about the importance of entrepreneurs financial reporting, whereas educational background, gender, and long standing business has no effect on the perception of entrepreneurs about the importance of financial reporting. Quality of the SME financial statements affect the amount of credit it receives. entrepreneurs variable information, socialization and last education of the SME entrepreneurs affect the understanding of the content SAK ETAP.
\end{abstract}

Keywords: Implementation, SAK ETAP, Financial Statements

\section{PENDAHULUAN}

UMKM (Usaha Mikro, Kecil dan Menengah) memiliki kontribusi yang sangat penting di dalam perekonomian Indonesia, baik dari segi unit usaha, penyerapan tenaga kerja, kontribusi terhadap produk domestik bruto, ekspor dan investasinya. Salah satu peranan tersebut ditandai dengan besarnya kontribusi UMKM terhadap besarnya Produk Domestik Bruto (PDB) beberapa tahun terakhir ini. Meningkatnya peranan ini dikarenakan UMKM lebih fleksibel dalam menghadapi dan beradaptasi dengan perubahan pasar, selain itu UMKM juga lebih diuntungkan oleh pertumbuhan ekonomi suatu lingkungan, dimana pasar berfungsi secara efektif dalam menyediakan berbagai jasa yang memungkinkan pertumbuhan bisnis.

UMKM setiap tahunnya mengalami perkembangan di dalam kontribusinya terhadap produk domestik bruto. Mulai dari tahun 2005, peran UMKM terhadap penciptaan PDB Nasional sekitar 1.491,6 triliun atau sekitar 53,5 persen dan selebihnya adalah usaha besar. Tahun 2010 tercatat kontribusi UMKM terhadap PDB Indonesia mencapai 57,12 persen atau senilai 
Rp 3.466,39 triliun, sedangkan untuk tahun 2011 UMKM mampu memberi kontribusi lebih besar lagi terhadap PDB Indonesia yakni 57,94 persen atau senilai $\mathrm{Rp} 3.123,51$ triliun.

Tingginya penyerapan tenaga kerja merupakan pembuktian besarnya kontribusi dari sektor UMKM, mulai tahun 2006, UMKM tercatat mampu menyerap tenaga kerja sebanyak 85.416.493 orang atau 96,18 persen dari total penyerapan tenaga kerja di Indonesia, jumlah ini meningkat sebesar 2,62 persen atau 2.182.700 orang dibandingkan tahun 2005. Kontribusi Usaha Kecil tercatat sebanyak 80.933.384 orang atau 91,14 persen dan Usaha Menengah sebanyak 4.483.109 orang atau 5,05 persen. Pada tahun 2011, UMKM mampu menyerap tenaga kerja sebesar 101.722.458 orang atau 97,24 persen dari total penyerapan tenaga kerja yang ada, jumlah ini meningkat sebesar 0,02 persen atau 2.182.700 orang dibandingkan tahun 2010. Kontribusi UK tercatat sebanyak 99.401.775 orang atau 97,22 persen. Sekitar 99 persen dari jumlah unit usaha di Indonesia berskala UMKM, dan tercatat mampu menciptakan lapangan pekerjaan sebanyak sekitar 99,4 juta tenaga kerja. Sementara, usaha besar menyerap sekitar 2,8 juta pekerja (data Kementerian Koperasi dan Usaha Kecil Menengah Tahun 2010).

Tahun 2010 jumlah unit UMKM di Indonesia mencapai 52,2 juta unit usaha yang tersebar di seluruh wilayah Indonesia, sedangkan berdasarkan Data Kementerian Koperasi dan UKM tahun 2012 memperkirakan jumlah UKM di Indonesia sebesar 56,5 juta unit atau mencapai 99,9 persen dari jumlah pelaku usaha di Indonesia, tumbuh sebesar 2,47 persen dibandingkan tahun 2011, dan tahun tahun sebelumnya.

Jumlah UMKM tersebut mencerminkan besarnya potensi yang dapat dikembangkan dan ditingkatkan bagi UMKM untuk dapat lebih berkontribusi bagi negeri ini. UMKM mampu bertahan dari beberapa gelombang krisis yang pernah terjadi di negeri ini, seperti krisis ekonomi
1997-1998 dan krisis ekonomi global 2008. UMKM mampu menyerap para pengangguran untuk dapat bekerja kembali di saat banyak perusahaan besar yang bangkrut dan melakukan pemutusan hubungan kerja (PHK). UKM memberikan kontribusi yang sama besarnya di banyak negara seperti yang terdapat di Indonesia. Tercatat jumlah UKM di negara maju rata-rata mencapai 90 persen dari total seluruh unit usaha, dan menyerap $2 / 3$ tenaga kerja dari jumlah pengangguran yang ada (Baas dan Schrooten, 2006). Afrika Selatan merupakan salah satu negara dengan 95 persen sektor usahanya merupakan UMKM. Sektor ini setiap tahunnya rata-rata memberikan kontribusi sebesar 35 persen terhadap produk domestik bruto, serta mampu mengurangi sebanyak 50 persen tingkat pengangguran di negara tersebut (Zimele, 2009).

Pencapaian yang luar biasa dan potensi yang besar dari UMKM tersebut sering terkendala masalah permodalan untuk mengembangkan usaha serta masalah pemasaran produk kepada masyarakat. Pada dasarnya UMKM memliki peluang yang besar untuk mendapatkan kredit sebagai suntikan modal. Hingga saat ini banyak program pembiayaan bagi UMKM baik yang dijalankan oleh pemerintah maupun oleh perbankan. Salah satu program pemerintah Indonesia terkait pembiayaan UMKM adalah Kredit Usaha Rakyat yang pada tahun 2009 ditargetkan sekitar Rp20 triliun. Tujuan dari KUR tersebut adalah untuk menjadi solusi pembiayan modal yang efektif bagi UMKM, sebab selama ini banyak UMKM yang terkendala untuk akses terhadap perbankan untuk mendapatkan bantuan pembiayaaan (Osa, 2010).

Namun pada prakteknya realisasinya jauh dari target Rp20 triliun yakni hanya sebesar Rp14,8 triliun. Penyebab rendahnya penyaluran KUR tersebut karena bank yang ditunjuk sebagai penyalur KUR masih telalu berhati-hati dalam penyaluran kredit, karena tidak memiliki akses informasi yang memadai terkait kondisi UMKM. 
Mayoritas pengusaha UMKM tidak mampu memberikan informasi akuntansi terkait kondisi usahanya sehingga membuat informasi tersebut menjadi lebih mahal bagi perbankan (Baas dan Schrooten, 2006).

Akuntansi yang memadai bagi pengusaha UMKM dapat digunakan sebagai salah satu untuk memenuhi persyaratan dalam pengajuan kredit, yang didalamnya berupa laporan keuangan, mengevaluasi kinerja, mengetahui posisi keuangan, menghitung pajak, dan manfaat lainnya (Warsono, 2009). Pelaksanaan pembukuan akuntansi untuk menghasilkan laporan keuangan merupakan hal yang masih sulit bagi UMKM. Keterbatasan pengetahuan pembukuan akuntansi, rumitnya proses akuntansi, dan anggapan bahwa laporan keuangan bukanlah hal yang penting bagi UMKM (Said, 2009). Berbagai macam keterbatasan lain dihadapi oleh UMKM mulai dari latar belakang pendidikan yang tidak mengenal mengenai akuntansi atau tata buku, kurang disiplin dan rajinnya dalam pelaksanaan pembukuan akuntansi, hingga tidak adanya kecukupan dana untuk mempekerjakan akuntan atau membeli software akuntansi untuk mempermudah pelaksanaan pembukuan akuntansi.

Terkait dengan kondisi tersebut di atas, Dewan Standar Akuntansi Keuangan (DSAK) pada tahun 2009 telah mensahkan Standar Akuntansi untuk Entitas Tanpa Akuntabilitas Publik (SAK ETAP). SAK ETAP tersebut berlaku efektif per 1 Januari 2011. Penggunaan SAK ETAP ini adalah ditujukan untuk entitas tanpa akuntabilitas publik yakni entitas yang 1) Tidak memiliki akuntabilitas publik yang signifikan, dan 2) Entitas yang menerbitkan laporan keuangan untuk tujuan umum bagi pengguna eksternal.

Tujuan Pemerintah dimasa yang akan datang, tentu sangat diharapkan UMKM mampu melakukan pembukuan akuntansi untuk menyajikan laporan keuangan yang lebih informatif dengan tujuan tentunya memberikan kemudahan bagi investor maupun kreditor untuk memberikan bantuan pembiayaan bagi para pengusaha UMKM. Berdasarkan hal tersebut, maka menarik untuk dilakukan penelitian mengenai bagaimana kualitas laporan keuangan yang selama ini dibuat oleh UMKM, apakah kualitas laporan tersebut berpengaruh pada besaran kredit yang disetujui oleh bank, dan menilai bagaimana prospek dari penerapan SAK ETAP di tahun 2011 terkait perbaikan kualitas laporan keuangan yang didasarkan pada pemahaman yang dimiliki oleh pengusaha UMKM terkait SAK ETAP tersebut.

SAK Entitas Tanpa Akuntabilitas Publik merupakan salah satu Standar Akuntansi yang penggunaannya ditujukan untuk entitas usaha yang tidak memiliki akuntabilitas publik, seperti entitas usaha mikro, kecil dan menengah (UMKM). Secara umum SAK ETAP ini lebih mudah dipahami dan tidak sekompleks SAK umum. Kemudahan lain bagi UMKM dalam hal pembukuan akuntansi selain adanya SAK ETAP tersebut adalah semakin banyaknya software akuntansi buatan dalam negeri maupun luar negeri yang telah secara khusus dirancang bagi UMKM seperti Zahir dan Oracle. Kelak diharapkan UMKM mampu melakukan pembukuan akuntansi untuk menyajikan laporan keuangan yang lebih informatif dengan tujuan tentunya memberikan kemudahan bagi investor maupun kreditur untuk memberikan bantuan pembiayaan bagi para pengusaha UMKM.

Penelitian ini merupakan pengembangan berdasarkan saran dan keterbatasan dari penelitian sebelumnya yang dilakukan oleh Rudiantoro dan Siregar (2011), target penelitian yang dituju serta obyek penelitian pada penelitian ini dikhususkan pada UMKM wilayah Kota dan Kabupaten se eks karesidenan kedu (Kota Magelang, Kabupaten Magelang, Temanggung, Wonosobo, dan Purworejo), dengan menyebar kuesioner seperti yang dilakukan peneliti sebelumnya. Selain itu peneliti juga ingin mengetahui apakah 
SAK ETAP sudah tersosialisasi dan diterapkan oleh para pengusaha UMKM di wilayah Kota dan Kabupaten eks karesidenan kedu.

Tujuan dari penelitian ini adalah untuk membuktikan faktor-faktor apa saja yang berpengaruh terhadap persepsi pengusaha terkait pentingnya pembukuan dan pelaporan keuangan bagi usahanya serta pemahaman pengusaha UMKM di Kota dan Kabupaten eks karesidenan kedu. Disamping itu juga membuktikan pengaruh kualitas laporan keuangan terhadap semakin besarnya jumlah kredit perbankan yang diterima oleh UMKM di Kota dan Kabupaten eks karesidenan kedu. Selain itu penelitian ini diharapkan dapat bermanfaat sebagai masukan untuk mengevaluasi pengusaha UMKM di Kota dan Kabupaten Magelang terkait pentingnya penggunaan laporan keuangan yang baik dan sebagai pengetahuan lebih lanjut terkait informasi SAK ETAP.

\section{REVIEW LITERATUR DAN HIPOTESIS}

\section{Teori Entitas}

Teori entitas menekankan pada konsep kepengelolaan "stewardship" dan pertanggungjawaban "accountability" dimana bisnis peduli dengan tingkat keberlangsungan usaha dan informasi keuangan usaha bagi pemilik ekuitas dalam rangka pemenuhan kebutuhan legal dan menjaga suatu hubungan baik dengan pemegang ekuitas tersebut dengan harapan mudah memperoleh dana di masa depan. Konsep entitas berlaku untuk firma, perusahaan perseorangan, korporasi (baik berupa perseroan maupun nonperseroan), serta perusahaan kecil dan besar. (Paton, 1962 dalam Suwardjono, 2005).

Teori Entitas (Entity Theory) memandang entitas sebagai sesuatu yang terpisah dan berbeda dari mereka yang menyediakan modal bagi entitas tersebut.Sederhananya unit bisnis dan bukanya pemilik, yang menjadi pusat dari kepentingan akuntansi.Unit bisnis memiliki sumber daya perusahaan dan bertanggung jawab baik atas klaim pemilik maupun klaim kreditor

\section{Laporan Keuangan}

Laporan keuangan merupakan hal penting yang wajib dimiliki oleh setiap organisasi, baik perusahaan yang berorientasi pada laba maupun organisasi nirlaba. Menurut Harahap (2010, h.105), "Laporan keuangan menggambarkan kondisi keuangan dan hasil usaha suatu perusahaan pada saat tertentu atau jangka waktu tertentu'.

Menurut Ikatan Akuntan Indonesia dalam Standar Akuntansi Keuangan (Revisi 2009, h.5, par.9), "Laporan keuangan adalah suatu penyajian terstruktur dari posisi keuangan dan kinerja keuangan suatu entitas".Berdasarkan ketiga uraian tersebut dapat disimpulkan bahwa laporan keuangan merupakan bentuk pertanggungjawaban keuangan perusahaan atas suatu aktivitas dalam menilai kondisi keuangan perusahaan.

Laporan keuangan adalah dokumendokumen yang melaporkan kegiatan bisnis pribadi atau organisasi. Para pengambil keputusan menggunakan informasi akuntansi untuk mengembangkan rencana bisnis mereka. Siklus ini akan terus berlanjut sebagaimana sistem akuntansi mengukur hasil kegiatan-kegiatan dan melaporkan hasil-hasil tersebut kepada para pengambil keputusan.

Tujuan laporan keuangan adalah menyediakan informasi posisi keuangan, kinerja keuangan, dan laporan arus kas suatu entitas yang bermanfaat bagi sejumlah besar pengguna dalam pengambilan keputusan ekonomi oleh siapapun yang tidak dalam posisi dapat meminta laporan keuangan khusus untuk memenuhi kebutuhan informasi tertentu (SAK, 2009

\section{SAK ETAP}

Ikatan Akuntan Indonesia telah menerbitkan Standar Akuntansi Keuangan untuk Entitas Tanpa Akuntabilitas Publik (SAK-ETAP) 
yang dapat diterapkan untuk penyusunan laporan keuangan yang dimulai pada atau setelah 1 Januari 2010.

Beberapa hal SAK ETAP memberikan banyak kemudahan untuk perusahaan dibandingkan dengan PSAK dengan ketentuan pelaporan yang lebih kompleks. Perbedaan secara kasat mata dapat dilihat dari ketebalan SAK-ETAP yang hanya sekitar seratus halaman dengan menyajikan 30 bab.

Sesuai dengan ruang lingkup SAK-ETAP maka Standar ini dimaksudkan untuk digunakan oleh entitas tanpa akuntabilitas publik. Entitas tanpa akuntabilitas publik yang dimaksud adalah entitas yang tidak memiliki akuntabilitas publik signifikan; dan menerbitkan laporan keuangan untuk tujuan umum (general purpose financial statement) bagi pengguna eksternal. Contoh pengguna eksternal adalah pemilik yang tidak terlibat langsung dalam pengelolaan usaha, kreditur, dan lembaga pemeringkat kredit.

Latar belakang penyusunan dan penerbitan SAK-ETAP ini adalah untuk memberikan kemudahan bagi entitas skala kecil dan menengah. Bahwa SAK yang berbasis IFRS (SAK Umum) ditujukan bagi entitas yang mempunyai tanggung jawab publik signifikan dan entitas yang banyak melakukan kegiatan lintas negara.SAK umum tersebut rumit untuk dipahami serta diterapkan bagi sebagian besar entitas usaha di Indonesia yang berskala kecil dan menengah. SAK ETAP memberikan banyak kemudahan untuk suatu entitas dibandingkan dengan SAK Umum dengan ketentuan pelaporan yang lebih kompleks.

\section{Hipotesis}

Perkembangan sektor UKM yang demikian pesat memperlihatkan bahwa terdapat potensi yang besar jika hal ini dapat dikelola dan dikembangkan dengan baik yang tentunya akan dapat mewujudkan usaha menengah yang tangguh. Sisi yang lain UKM juga masih dihadapkan pada masalah yang terletak pada proses administrasi.
Masalah utama dalam pengembangan UKM yaitu mengenai pengelolaan keuangan dalam usahanya tersebut, karena pengelolaan yang baik memerlukan keterampilan akuntansi yang baik pula oleh pelaku bisnis UKM. Pemerintah sudah mencoba membantu mengatasi kendala yang dihadapi oleh sebagian besar UKM, seperti melakukan pembinaan dan pemberian kredit lunak.

Beberapa hal yang dapat mempengaruhi persepsi pengusaha terkait pentingnya pembukuan dan pelaporan keuangan bagi tumbuh dan berkembangnya usaha seperti harapan terkait ukuran usaha ke depannya, pengalaman yang didapat dari lama usaha berdiri, latar belakang pendidikan, serta jenjang pendidikan terakhir.

Praktik akuntansi, khususnya akuntansi keuangan pada UKM di Indonesia masih rendah dan memiliki banyak kelemahan (Wahdini \& Suhairi, 2006). Kelemahan itu, antara lain disebabkan rendahnya pendidikan. Murniati (2002) menemukan bahwa pengusaha dengan jenjang pendidikan formal yang rendah cenderung tidak memiliki persiapan dan penggunaan informasi akuntansi yang memadai dibandingkan pengusaha yang memiliki pendidikan formal lebih tinggi

Pinasti (2001) menemukan bahwa ukuran usaha merupakan faktor yang sulit dipisahkan dengan lingkungan pengusaha UMKM. Lama suatu usaha berdiri diharapkan dapat memberikan pengaruh terhadap persepsi pengusaha UMKM yang terbentuk. Faktor lain yang erat hubungannya dengan proses belajar adalah latar belakang pendidikan. Latar belakang pengusaha, jenis kelamin dan target pasar hasil produksi UMKM baik yang berasal dari bidang akuntansi maupun ekonomi atau bidang lainnya dapat mempengaruhi persepsinya terkait pentingnya pembukuan dan pelaporan keuangan bagi tumbuh dan berkembangnya usaha. Hipotesis yang diajukan dalam penelitian ini sebagai berikut: 
H1a Jenis Kelamin berpengaruh positif terhadap persepsi pengusaha terkait pentingnya pembukuan dan pelaporan keuangan bagi usahanya.

H1b Jenjang pendidikan terakhir berpengaruh positif terhadap persepsi pengusaha terkait pentingnya pembukuan dan pelaporan keuangan bagi usahanya.

H1c Ukuran usaha berpengaruh positif terhadap persepsi pengusaha terkait pentingnya pembukuan dan pelaporan keuangan bagi usahanya.

H1d Lama usaha berdiri berpengaruh positif terhadap persepsi pengusaha terkait pentingnya pembukuan dan pelaporan keuangan bagi usahanya.

H1e Latar belakang pendidikan berpengaruh positif terhadap persepsi pengusaha terkait pentingnya pembukuan dan pelaporan keuangan bagi usahanya

H1f Pangsa Pasar/target Pemasaran berpengaruh positif terhadap persepsi pengusaha terkait pentingnya pembukuan dan pelaporan keuangan bagi usahanya.

UKM apabila berkeinginan memperoleh tambahan modal juga dituntut menyertakan laporan keuangan sebagai syarat mengajukan pinjaman kepada pihak bank. Pihak perbankan sendiri tidak ingin mengambil risiko dalam penyaluran kredit bagi UKM dikarenakan perbankan tidak mengetahui perkembangan usaha tersebut.Sementara hampir semua UKM tidak memiliki laporan kinerja usaha dan keuangan yang baik sebagai syarat untuk memperoleh kredit. Hal ini terjadi karena UKM tidak dibiasakan untuk melakukan pencatatan dan penyusunan laporan keuangan sebagai gambaran kegiatan usaha dan posisi keuangan perusahaan, padahal dengan adanya laporan keuangan akan memungkinkan pemilik memperoleh data dan informasi yang tersusun secara sistematis
Menurut Baas dan Schrooten (2006) bahwa salah satu teknik pemberian kredit yang paling banyak digunakan adalah financial statement lending yang mendasarkan pemberian kreditnya atas informasi keuangan dari debiturnya. Namun di sisi lain hal tersebut menjadi kendala tersendiri sebab UMKM ternyata tidak mampu menyediakan informasi yang diperlukan oleh bank tersebut.

Berdasarkan kondisi dan penelitian sebelumnya, maka rumusan hipotesis yang diajukan adalah:

H2 Kualitas laporan keuangan berpengaruh positif terhadap semakin besarnya jumlah kredit perbankan yang diterima oleh UMKM

Kebanyakan dari UKM hanya mencatat jumlah uang yang diterima dan dikeluarkan, jumlah barang yang dibeli dan dijual, dan jumlah piutang / utang. Namun, pencatatan itu hanya sebatas pengingat saja dan tidak dengan format yang diinginkan oleh pihak perbankan. Meskipun tidak dapat dipungkiri mereka dapat mengetahui jumlah modal akhir mereka setiap tahun yang hampir sama jumlahnya jika kita mencatat dengan sistem akuntansi (H. Jati, Beatus B., Otniel N., 2004). Akuntansi merupakan indikator kunci kinerja usaha, informasi akuntansi berguna bagi pengambilan keputusan sehingga dapat meningkatkan pengelolaan perusahaan.

Hal ini telah mendorong komite Standar Akuntansi Internasional (The International Accounting Standards Board) untuk menyusun Standar Akuntansi Keuangan yang khusus bagi UKM.Saat ini telah diterbitkan SAK baru khusus untuk ETAP (Entitas Tanpa Akuntabilitas Publik) dalam rangka pengembangan standar akuntansi bagi UKM.

Pemahaman terkait SAK ETAP tersebut erat kaitannya dengan proses pemberian informasi dan sosialisasi. Apabila pengusaha mendapatkan informasi dan sosialisasi dengan baik, maka 
pemahaman mereka terkait SAK ETAP akan menjadi lebih baik dan mendukung proses implementasi SAK ETAP di tahun 2011. Selain proses pemberian informasi dan sosialisasi terkait SAK ETAP, mungkin terdapat pengaruh dari jenis kelamin, latar belakang pendidikan, pendidikan terakhir, lama usaha berdiri dan ukuran usaha dari pengusaha UMKM terhadap pemahamannya. Berdasarkan penjelasan tersebut, maka hipotesis yang diajukan adalah sebagai berikut:

H3a Jenis kelamin berpengaruh positif terhadap pemahaman pengusaha UMKM terkait SAK ETAP.

H3b Pemberian informasi dan sosialisasi SAK ETAP berpengaruh positif terhadap pemahaman pengusaha UMKM terkait SAK ETAP.

H3c Latar belakang pendidikan pengusaha berpengaruh positif terhadap pemahaman pengusaha UMKM terkait SAK ETAP.

H3d Jenjang pendidikan terakhir pengusaha berpengaruh positif terhadap pemahaman pengusaha UMKM terkait SAK ETAP.

H3e Lama Usaha berdiri berpengaruh positif terhadap pemahaman pengusaha UMKM terkait SAK ETAP.

H3f Ukuran usaha berpengaruh positif terhadap pemahaman pengusaha UMKM terkait SAK ETAP.

H3g Omzet berpengaruh positif terhadap pemahaman pengusaha UMKM terkait SAK ETAP.

\section{METODE PENELITIAN}

\section{Populasi dan Sampel}

Populasi dalam penelitian ini adalah UMKM yang yang ada di wilayah eks karesidenan Kedu. Metode pengumpulan sampel dengan metode purposive sampling yaitu pemilihan sampel dengan kriteria tertentu. Adapun kriteria sampel penelitian adalah sebagai berikut :

a. Usaha Kecil dan menengah yang terdaftar pada Dinas Perindustrian dan Perdagangan di wilayah Eks Karesidenan Kedu.

b. Usaha Kecil dan menengah yang usahanya bergerak pada bidang jasa dan perdagangan maupun industry

c. Usaha Kecil menengah binaan

\section{Alat Uji Analisis \\ Uji Validitas}

Uji ini digunakan untuk mengetahui validitas data dan keandalan yang dihasilkan dalam penelitian ini untuk menguji kevalitan atau tidak daftar pertanyaan yang diajukan peneliti dalam kuesioner ini. Instrumen memiliki validitas konstruk atau tidak, dapat dilihat dari koefisien pengaruh diperoleh dengan menggunakan teknik Product Moment yang menghitung masingmasing pertanyaan dengan skor total. Variabel dikatakan valid, apabila uji validitas peneliti diperoleh signifikan jika $r_{\text {hitung }}$ lebih besar, apabila dibandingkan nilai $r_{\text {tabel }}$ (Ghozali, 2009).

\section{Uji Reliabilitas}

Reliabilitas adalah alat ukur untuk mengukur suatu kuesioner yang merupakan indikator dari variabel. Suatu kuesioner dikatakan variabel atau handal jika jawaban seseorang terhadap pertanyaan adalah konsisten atau stabil dari waktu ke waktu dengan menggunakan alat ukur yang sama. Pengujian dilakukan dengan menghitung Cronbach Alpha dari masing-masing instrumen dalam suatu variabel. Instrumen yang dipakai dalam variabel tersebut dikatakan handal/ reliabel jika memberi nilai Cronbach Alpha $(\alpha)$ lebih dari 0,6.

\section{Uji $R$-Square $\left(\mathbf{R}^{2}\right)$}

Uji $R^{2}$ mengukur seberapa jauh kemampuan model dalam menerangkan variabel dependen (Ghozali, 2009). Besarnya koefisien dari 0 sampai 1 semakin mendekati 0 besarnya koefisien determinasi semakin kecil pengaruh 
semua variabel bebas, sebaliknya mendekati 1 besarnya koefisien determinasi (Uji $\mathrm{R}^{2}$ ) semakin besar pengaruh variabel bebas.

\section{Analisis Regresi}

\section{Model 1:}

$\mathrm{PS}=\alpha 1+\alpha 2 \mathrm{JK}+\alpha 3 \mathrm{PT}+\alpha 4 \mathrm{SZ}+\alpha 5 \mathrm{LU}+$ $\alpha 6 \mathrm{LB}+\alpha 7 \mathrm{PP}+\mathrm{e}$

\section{Model 2:}

$\mathrm{CAt}=\alpha 1+\alpha 2 \mathrm{KW}+\mathrm{e}$

\section{Model 3:}

$$
\begin{gathered}
\mathrm{UNt}=\alpha 1+\alpha 2 \mathrm{JK}+\alpha 3 \mathrm{IS}+\alpha 4 \mathrm{LB}+\alpha 5 \mathrm{PT}+ \\
\alpha 6 \mathrm{LU}+\alpha 7 \mathrm{SZ}+\alpha 2 \mathrm{OZ}+\mathrm{e}
\end{gathered}
$$

Keterangan:

$$
\begin{aligned}
& \alpha=\text { Intercept } \\
& \beta_{1,2,3}=\text { Koefisien regresi } \\
& \mathrm{JK}=\text { Jenis kelamin pengusaha } \\
& \mathrm{SZ}=\text { ukuran usaha UMKM } \\
& \mathrm{LU}=\text { lama usaha berdiri } \\
& \mathrm{CR}=\text { jumlah kredit yang diajukan oleh } \\
& \text { UMKM } \\
& \mathrm{CA}=\text { jumlah kredit yang diterima oleh } \\
& \text { UMKM } \\
& \mathrm{PP}=\text { Pangsa Pasar } / \text { Target pasar hasil } \\
& \text { produksi. }
\end{aligned}
$$

\section{HASIL PENELITIAN DAN PEMBAHASAN}

\section{Sampel Penelitian}

Sampel penelitian ini diambil dari UMKM binaan yang berada diwilayah eks karesidenan kedu, yaitu Kabupaten Magelang, Temanggung, Wonosobo, Purworejo, Kebumen, dan Kota Magelang. Kuesioner yang disebar sebanyak 150 Kuesioner, dan berdasarkan kuesioner yang tersebar kepada responden, 117 kuesioner kembali, namun demikian ada 11 kuesioner yang pengisiannya tidak lengkap, dan sisanya tidak kembali.

Tabel 1
Pengambilan Sampel
\begin{tabular}{|l|c|}
\hline \multicolumn{1}{|c}{ Keterangan } & Jumlah \\
\hline UMKM di Kota Magelang yang & 150 \\
menjadi sampel & $(33)$ \\
Kuesioner tidak kembali & $(11)$ \\
Kuesioner tidak lengkap & \\
\hline $\begin{array}{l}\text { Jumlah UMKM yang memenuhi } \\
\text { kriteria }\end{array}$ & 106 \\
\hline
\end{tabular}

Sumber : hasil olah data

\section{Statistik Deskriptif}

Persebaran sampel berdasarkan lokasi usahanya adalah sebanyak 150 responden yang berada di wilayah karesidenan kedu, yang meliputi Kabupaten Magelang, Temanggung, Wonosobo, Purworejo, Kebumen, dan Kota Magelang. Pendidikan formal terakhir yang ditempuh oleh para responden (PT), didominasi lulusan SMA/ SMK yakni sebanyak 66 responden, sedangkan lulusan S1 sebanyak 12 responden, dan sisanya 28 responden berpendidikan SD dan SMP. Berdasarkan jenis usaha yang dijalankan (JNS), mayoritas responden bergerak dalam bidang manufaktur atau produksi barang yaitu sebanyak 53 responden, kemudian perdangan atau jual beli sebanyak 27 responden, 16 responden usahanya bergerak di bidang jasa, dan 10 responden di bidang bergerak di bidang agrobisnis (pertanian). 
Pengelompokan perusahaan berdasarkan ukuran usahanya (SZ), 74 perusahaan masuk kedalam kelompok perusahaan mikro, 27 perusahaan masuk dalam kelompok perusahaan kecil, dan sisanya 5 perusahaan masuk dalam kelompok perusahaan menengah. Jika dikelompokkan berdasarkanlama usaha berdirinya perusahaan (LU), 57\% berdiri dalam kurun waktu kurang dari 5 tahun, 31\% masuk dalam kelompok 5 sampai dengan 10, dan $11 \%$ masuk dalam kelompok lebih dari 10 tahun. Hal ini menunjukkan secara umum UKM yang menjadi responden mempunyai kebutuhan untuk menghasilkan laporan keuangan. Persepsi pentingnya pembukuan dan pelaporan keuangan tersebut kemungkinan muncul dari semakin besarnya kebutuhan untuk memiliki suatu laporan keuangan untuk berbagai tujuan seperti persyaratan pengajuan kredit, evaluasi usaha, dan sebagai input untuk keputusan melakukan ekspansi usaha. Basri dan Nugroho (2009) menyebutkan bahwa permasalahan utama dari UKM berkaitan dengan manajemen keuangan, pengajuan kredit, pelatihan keahlian tenaga kerja, pelatihan kewirausahaan dan lain-lain. Banyak dari pengusaha UMKM mulai memperhatikan proses pembukuan dan pelaporan keuangan untuk dapat mengatasi permasalahan manajemen keuangan serta kredit tersebut.

Variabel kualitas laporan keuangan (KW) terlihat kualitas laporan keuangan memiliki kisaran yang cukup lebar dan nilai standar deviasi yang cukup tinggi, yang menunjukkan kualitas laporan keuangan yang dihasilkan responden cukup bervariasi. Lebih lanjut, berdasarkan variabel pemahaman SAK ETAP (UN) terlihat bahwa 84\% dari responden belum mengetahui dan belum paham mengenai SAK ETAP. Kemungkinan penyebabnya adalah karena tingkat informasi dan sosialisasi (INFO) SAK ETAP yang diterima mereka masih relatif terbatas, terlihat bahwa 89 responden atau $84 \%$ responden mengaku belum pernah menerima sosialisasi dan informasi yang memadai terkait SAK ETAP.

Hubungan antar variabel dapat dilihar dari hasil korelasi antar variabel, yang ditunjukkan pada tabel (lampiran). Variabel persepsi (PS) berhubungan kuat dengan pendidikan terakhir (PT), ukuran usaha (SZ), dan pangsa pasar(PP). Hal tersebut memberikan indikasi bahwa variabel pendidikan terakhir, ukuran usaha, dan pangsa pasar akan berpengaruh terhadap persepsi pengusaha terhadap pentingnya laporan keuangan UMKM.

Hubungan antar variabel lainnya dapat dilihat pada pengujian korelasi yang ditunjukkan pada tabel berikutnya. Variabel besarnya Jumlah Kredit (CA), berhubungan Kuat dengan Kualitas Laporan Keuangan UMKM (KW), sehingga hal tersebut juga memberikan indikasi kuat bahwa kualitas laporan keuangan berpengaruh terhadap besarnya kredit yang diberikan perbankan kepada UMKM.

Hubungan antar variabel lainnya juga dapat dilihat pada pengujian korelasi yang ditunjukkan pada tabel berikutnya. Pada pengujian ini, Pemahaman responden mengenai SAK ETAP (UN), berhubungan kuat dengan Informasi yang dilakukan (IS), pendidikan terakhir (PT), ukuran usaha (SZ), dan besarnya omset perusahaan (OMZ). Hal tersebut mengindikasikan secara awal, bahwa variabel Informasi dan sosialisasi, pendidikan terakhir, ukuran usaha, dan besarnya omset berpengaruh terhadap pemahaman responden mengenai SAK ETAP.

Model 1: PS $=\alpha 1+\alpha 2 \mathrm{JK}+\alpha 3 \mathrm{PT}+\alpha 4 \mathrm{SZ}+$ $\alpha 5 \mathrm{LU}+\alpha 6 \mathrm{LB}+\alpha 7 \mathrm{PP}+\mathrm{e}$

Tabel 2

Hasil Regresi Model 1

\begin{tabular}{|c|c|c|c|}
\hline Variabel & Beta & Nilai t & P-value (sig) \\
\hline JK & $-0,064$ &,- 0673 & 0,503 \\
PT & 0,287 & 3,013 & 0,003 \\
SZ & 0,134 & 1,207 & 0,230 \\
LU & $-0,061$ & $-0,627$ & 0,532 \\
LB & $-0,077$ & $-0,837$ & 0,404 \\
PP & 0,173 & 1,620 & 0,108 \\
\hline
\end{tabular}

Sumber: hasil olah data 
Pengaruh jenis kelamin terhadap persepsi pengusaha terkait pentingnya pembukuan dan pelaporan keuangan bagi usahanya

Hasil penelitian diperoleh nilai signifikansi sebesar 0,503 lebih besar dari 0,05, artinya jenis kelamin (JK) tidak berpengaruh terhadap persepsi pengusaha terkait pentingnya pembukuan dan pelaporan keuangan bagi usahanya, sehingga hipotesis 1a tidak diterima.

Pengaruh pendidikan terakhir terhadap persepsi pengusaha terkait pentingnya pembukuan dan pelaporan keuangan bagi usahanya

Hasil penelitian diperoleh nilai signifikansi atau probabilitas sebesar 0,003 lebih kecil dari 0,05, artinya pendidikan terakhir (PT) berpengaruh terhadap persepsi pengusaha terkait pentingnya pembukuan dan pelaporan keuangan bagi usahanya, maka hipotesis $1 \mathrm{~b}$ diterima.

Pengaruh ukuran usaha terhadap persepsi pengusaha terkait pentingnya pembukuan dan pelaporan keuangan bagi usahanya

Hasil penelitian diperoleh nilai signifikansi atau probabilitas sebesar 0,230 kurang dari 0,05, artinya Ukuran usaha (SZ) tidak berpengaruh positif terhadap persepsi pengusaha UMKM, maka hipotesis $1 \mathrm{c}$ tidak diterima.

Pengaruh lama usaha terhadap terhadap persepsi pengusaha terkait pentingnya pembukuan dan pelaporan keuangan bagi usahanya

Hasil penelitian diperoleh nilai signifikansi atau probabilitas sebesar 0,532 lebih dari 0,05, artinya variabel lama usaha berdiri (LU) tidak berpengaruh signifikan terhadap persepsi pengusaha terkait pentingnya pembukuan dan pelaporan keuangan bagi usahanya, sehingga hipotesis $1 \mathrm{~d}$ tidak diterima.
Pengaruh latar belakang pendidikan terhadap persepsi pengusaha terkait pentingnya pembukuan dan pelaporan keuangan bagi usahanya

Hasil penelitian diperoleh nilai signifikansi atau probabilitas sebesar 0,404 lebih besar dari 0,05 , artinya latar belakang pendidikan (LB) tidak berpengaruh terhadap persepsi pengusaha terkait pentingnya pembukuan dan pelaporan keuangan bagi usahanya, maka hipotesis 1e tidak diterima. Hal ini mungkin disebabkan karena mayoritas latar belakang pendidikan responden yang bukan berasal dari bidang akuntansi maupun ekonomi, sehingga tidak menganggap pembukuan penting dilakukan secara teratur.

Pengaruh pangsa pasar terhadap persepsi pengusaha terkait pentingnya pembukuan dan pelaporan keuangan bagi usahanya

Hasil penelitian diperoleh nilai signifikansi atau probabilitas sebesar 0,108 lebih besar dari 0,05 , artinya pangsa pasar (PP) tidak berpengaruh terhadap persepsi pengusaha (PS), sehingga hipotesis 1f tidak diterima. Berdasarkan hasil kuesioner sekitar $80 \%$ responden (87 responden) menilai laporan keuangan sangat penting dalam perkembangan usaha. Dengan demikian, berdasarkan data tersebut dapat dikatakan bahwa pada dasarnya pengusaha UMKM memang telah menganggap bahwa pembukuan akuntansi dan pelaporan keuangan merupakan suatu hal yang penting bagi pertumbuhan dan perkembangana usaha mereka, serta menjadi bagian yang tidak terpisahkan dalam kegiatan usahanya. Persepsi pentingnya pembukuan dan pelaporan keuangan tersebut muncul dari semakin besarnya kebutuhan untuk memiliki suatu laporan keuangan untuk berbagai tujuan seperti persyaratan pengajuan kredit, evaluasi usaha, dan sebagai sumber informasi untuk ekspansi usaha. 
Basri dan Nugroho (2009) menyebutkan bahwa permasalahan utama dari UKM berkaitan dengan manajemen keuangan, pengajuan kredit, pelatihan keahlian tenaga kerja, pelatihan kewirausahaan dan lain-lain. Banyak dari pengusaha UMKM mulai memperhatikan proses pembukuan dan pelaporan keuangan untuk dapat mengatasi permasalahan manajemen keuangan serta kredit tersebut. Namun demikian, berdasarkan hasil regresi model 1 dapat diperoleh kesimpulan bahwa terdapat variabel yang berpengaruh terhadap persepsi mengenai pentingnya laporan keuangan tersebut. Salah satu variabel yang berpengaruh yaitu variabel pendidikan terakhir.

Model 2: $\mathrm{CAt}=\alpha 1+\alpha 2 \mathrm{KW}+\mathrm{e}$

Tabel 4

Hasil Regresi Model 2

\begin{tabular}{cccc}
\hline Variabel & Beta & Nilai t & $\begin{array}{c}\text { P-value } \\
\text { (sig) }\end{array}$ \\
\hline KW & 0,303 & 3,237 & 0,002 \\
\hline Sumber:
\end{tabular}

Sumber: hasil olah data

\section{Pengaruh kualitas laporan keuangan terhadap besarnya kredit yang diterima}

Hasilpenelitian diperoleh nilai signifikansi atau probabilitas sebesar 0,002 kurang dari 0,05, artinya kualitas laporan keuangan berpengaruh positif dan signifikan terhadap besarnya kredit yang diterima pihak UMKM saat mengajukan kredit ke pihak bank, maka hipotesis 2 diterima.

Hasil pengujian Model 2, Kualitas laporan keuangan UMKM berpengaruh signifikan terhadap besaran kredit yang diterimanya. Hal ini mengindikasikan bahwa laporan keuangan digunakan sebagai salah satu syarat dalam pengajuan kredit yang dilakukan oleh pihak perbankan. Hasil ini tidak konsisten dengan penelitian sebelumnya, yang menemukan bahwa laporan keuangan tidak berpengaruh signifikan terhadap besarnya kredit yang diterima, hal ini terjadi karena adanya kemungkinan bahwa laporan keuangan UMKM belum dapat menjadi sumber informasi yang andal dan relevan bagi perbankan. Kondisi ini serupa dengan Baas dan Schrooten (2006) yang berkesimpulan bahwa salah satu penyebab hampir di seluruh dunia UMKM mengalami kesulitan dalam mendapatkan kredit perbankan adalah adanya keterbatasan informasi bersifat Hard Information dengan kualitas yang sesuai dengan standar perbankan yang mampu diberikan oleh UMKM. Kualitas laporan keuangan yang masih tergolong rendah tersebut menjadi kendala sendiri bagi pihak perbankan untuk dapat mengandalkan informasi keuangan yang terdapat dalam laporna keuangan tersebut.

Laporan keuangan dari pengusaha UMKM menjadi salah satu persyaratan administrasi yang harus dipenuhi jika pengusaha hendak mengajukan kredit ke perbankan. Namun pengusaha UKM, terutama sektor mikro dan kecil, masih belum memiliki laporan keuangan yang dapat diandalkan sehingga dalam proses penentuan jumlah kredit yang diberikan akan ditentukan melalui faktor lain dengan bobot penilaian yang lebih besar dari pada ketersedian laporan keuangan, seperti hasil survey lapanagan dari usaha yang dijalankan, yang meliputi penilaian aset tetap yang dimiliki serta kegiatan usaha secara langsung, dan juga lamanya termin kredit yang diajukan, serta jaminan yang diberikan oleh pengusaha.

Model 3: UNt $=\alpha 1+\alpha 2 \mathrm{JK}+\alpha 3 \mathrm{IS}+\alpha 4 \mathrm{LB}+$ $\alpha 5 \mathrm{PT}+\alpha 6 \mathrm{LU}+\alpha 7 \mathrm{SZ}+\alpha 2 \mathrm{OZ}+\mathrm{e}$

Tabel 5

Hasil Regresi Model 3

\begin{tabular}{cccc}
\hline Variabel & Beta & Nilai t & P-value (sig) \\
\cline { 1 - 2 } JK & 0,14 & 0,463 & 0,645 \\
IS & 0,951 & 31,349 & 0,000 \\
LB & $-0,023$ & $-0,786$ & 0,433 \\
PT & 0,083 & 2,731 & 0,007 \\
LU & 0,034 & 1,097 & 0,275 \\
SZ & $-0,004$ & $-0,085$ & 0,932 \\
OMZ & $-0,074$ & $-1,389$ & 0,168 \\
\hline
\end{tabular}

Sumber: hasil olah data 
Pengaruh jenis kelamin terhadap besarnya pemahaman pengusaha terkait SAK ETAP

Hasil penelitian diperoleh nilai signifikansi sebesar 0,645 lebih besar dari 0,05, artinya jenis kelamin (JK) tidak berpengaruh terhadap besarnya pemahaman pengusaha terkait SAK ETAP, sehingga hipotesis 3a tidak diterima.

Pengaruh tingkat informasi dan sosialisasi yang diterima oleh pengusaha UMKM terkait penerapan SAK ETAP terhadap besarnya pemahaman pengusaha terkait SAK ETAP

Hasil penelitian diperoleh nilai signifikansi sebesar 0,000 lebih kecil dari 0,05, artinya tingkat informasi dan sosialisai (IS) berpengaruh terhadap besarnya pemahaman pengusaha terkait SAK ETAP, yang berarti hipotesis $3 \mathrm{~b}$ diterima.

\section{Pengaruh latar belakang pendidikan terhadap} besarnya pemahaman pengusaha terkait SAK ETAP

Hasil penelitian diperoleh nilai signifikansi atau probabilitas sebesar 0,433 lebih besar dari 0,05, artinya latar belakang pendidikan (LB) tidak berpengaruh terhadap besarnya pemahaman pengusaha terkait SAK ETAP, yang berarti hipotesis $3 \mathrm{c}$ tidak diterima.

Pengaruh pendidikan terakhir terhadap besarnya pemahaman pengusaha terkait SAK ETAP

Hasil penelitian diperoleh nilai signifikansi atau probabilitas sebesar 0,007 lebih kecil dari 0,05, artinya pendidikan terakhir (PT) berpengaruh terhadap besarnya pemahaman pengusaha terkait SAK ETAP, sehingga hipotesis $3 \mathrm{~d}$ diterima.

Pengaruh lama usaha terhadap terhadap besarnya pemahaman pengusaha terkait SAK ETAP

Hasil penelitian diperoleh nilai signifikansi atau probabilitas sebesar 0,275 lebih dari 0,05 , artinya variabel lama usaha berdiri (LU) tidak berpengaruh signifikan terhadap besarnya pemahaman pengusaha terkait SAK ETAP, sehingga hipotesis $3 e$ tidak diterima.

Pengaruh ukuran usaha usaha terhadap terhadap besarnya pemahaman pengusaha terkait SAK ETAP

Hasil penelitian diperoleh nilai signifikansi atau probabilitas sebesar 0,275 lebih dari 0,05 , artinya variabel ukuran usaha (SZ) tidak berpengaruh signifikan terhadap besarnya pemahaman pengusaha terkait SAK ETAP, maka hipotesis $3 f$ tidak diterima.

Pengaruh besarnya omset terhadap terhadap besarnya pemahaman pengusaha terkait SAK ETAP

Hasil penelitian diperoleh nilai signifikansi atau probabilitas sebesar 0,168 lebih dari 0,05 , artinya variabel omset (OMZ) tidak berpengaruh signifikan terhadap besarnya pemahaman pengusaha terkait SAK ETAP, yang berati hipotesis $3 \mathrm{~g}$ tidak diterima.

Hasil yang diperoleh pada regresi model 3 ini diproleh hasil bahwa Variabel informasi dan sosialisasi (IS) dan variabel pendidikan terakhir (PT) berpengaruh positif signifikan terhadap pemahaman pengusaha UMKM atas isi SAK tersebut Namun demikian, menurut mereka pelatihan yang diberikan adalah pelatihan teknik dasar dalam melakukan pembukuan akuntansi, seperti bagaimana melakukan penyimpanan bukti transaksi, seperti kwitansi, bon, faktur dan lainlain, serta pemberian teknik dasar pembukuan akuntansi seperti proses dalam siklus akuntansi hingga menyusun laporan keuangan. Pengusaha UMKM berpendapat bahwa masih sangat perlu adanya sosialisasi terkait SAK ETAP ini, lebih dari $60 \%$ responden menjawab penting dan sangat penting bahwa SAK ETAP masih harus dilakukan sosialisasi yang lebih baik dan tepat sasaran lagi.

Metode sosialisasi yang diharapkan oleh para pengusaha UMKM terkait SAK ETAP ini adalah dengan cara pelatihan yang berkelanjutan 
dengan pemberian modul praktek kepada para pengusaha. Menurut mereka cara ini dapat lebih langsung dipraktekkan pada usaha mereka. Selama ini pelatihan akuntansi ataupun sosialisasi yang ada lebih bersifat seminar sehari, sehingga hanya memberikan teori namun kurang dalam hal prakteknya. Untuk pihak yang dinilai paling bertanggung jawab untuk pelaksanaan sosialisasi ini adalah Kementerian Koperasi dan UMKM, sebab menurut responden pihak tersebutlah yang paling mengerti kondisi UMKM saat ini, mulai dari kondisi geografis, latar belakang pengusaha, jenis usaha serta kelompok usaha yang ada sehingga dimungkinkan pelatihan yang diberikan dapat sesuai dengan kebutuhan pengusaha UMKM. Variabel pendidikan terakhir (PT) juga berpengaruh signifikan terhadap pemahaman pengusaha UMKM terkait SAK ETAP. Kondisi ini kemungkinan terjadi karena Kemudahan daya tangkap atas suatu hal baru yang diterima seseorang dipengaruhi pendidikan seseorang. Mereka akan terbiasa memahami hal baru dengan lebih mudah dan cepat dibanding orang-orang yang memiliki jenjang pendidikan yang lebih rendah.

\section{KESIMPULAN DAN SARAN}

\section{Kesimpulan}

Berdasarkan hasil analisis data yang telah dilakukan dapat disimpulkan bahwa responden UMKM dalam penelitian ini memiliki persepsi bahwa pembukuan dan pelaporan keuangan merupakan hal yang penting dalam pertumbuhan dan perkembangan usahanya. Faktor pendidikan terakhir responden berpengaruh positif terhadap persepsi pengusaha terkait pentingnya pelaporan keuangan. Latar belakang pendidikan, jenis kelamin, serta lama usaha berdiri tidak berpengaruh terhadap persepsi pengusaha terkait pentingnya pelaporan keuangan, sehingga hasil tersebut berbeda dari dugaan awal peneliti. Berdasarkan hasil tersebut, jenjang pendidikan memiliki peran penting dan persepsi yang baik akan pentingnya pembukuan dan pelaporan keuangan, sebagai langkah awal dalam memberikan informasi dan kemajuan terhadap UMKM yang mereka kelola, sehingga dengan adanya laporan keuangan, langkah dalam pengendalian internal manajemen dan pengambilan keputusan manajemen dan evaluasi usahanya dapat dilakukan dengan mudah berdasarkan hasil dari laporan keuangan tersebut. Pentingnya pembukuan dan pelaporan keuangan tersebut juga muncul dari semakin besarnya kebutuhan untuk memiliki suatu laporan keuangan untuk berbagai tujuan seperti persyaratan pengajuan kredit, evaluasi usaha, dan sebagai sumber informasi untuk ekspansi usaha. Hal tersebut terbukti dari hasil penelitian bahwa kualitas laporan keuangan berpengaruh secara positif terhadap besarnya kredit yang diterima oleh UMKM, sehingga hal tersebut memicu UMKM yang belum memiliki laporan keuangan berusaha untuk membuat laporan keuangan yang berguna sebagai salah satu syarat dalam pengajuan kredit.

Kualitas laporan keuangan UMKM di Indonesia saat ini masih tergolong rendah, namun demikian masih rendahnya kualitas laporan keuangan UMKM menyebabkan kualitas laporan keuangan berpengaruh positif terhadap persepsi pengusaha terkait pentingnya pembukuan dan pelaporan keuangan bagi usahanya. Pemberian informasi dan sosialisasi pengusaha ternyata berpengaruh positif terhadap tingkat pemahaman pengusaha terkait laporan keuangan ini. Tingginya pendidikan terakhir juga berpengaruh positif terhadap pemahaman pengusaha mengenai pembukuan, hal ini mengindikasikan bahwa tinggi pendidikan, maka semakin faham juga terhadap laporan keuangan dan pembukuan, disamping itu, laporan keuangan juga merupakan salah satu syarat untuk mengajukan permohonan kredit. Variabel lain seperti latar belakang pendidikan, pendidikan terakhir tidak berpengaruh pada pemahaman pengusaha terkait pentingnya pembukuan dan pelaporan keuangan 
bagi usahanya terkait laporan keuangan. Kondisi tersebut dapat menjadi bahan evaluasi bahwa selama ini pemberian informasi dan sosialisasi masih belum efektif dan mencapai target yang diinginkan.

\section{Saran}

Penelitian ini memiliki beberapa keterbatasan diantaranya:

1. Penggunaan range jawaban pada beberapa pertanyaan dalam kuesioner, dapat menurunkan kualitas data dalam penelitian ini.

2. Masih terdapat beberapa variabel lain yang tidak signifikan dalam pembentukan persepsi pengusaha dan belum dimasukkannya variabel lain yang diduga memiliki kemungkinan untuk berpengaruh terhadap pembentukan persepsi pengusaha seperti variabel latar belakang keluarga

Saran penelitian selanjutnya adalah terkait responden yang dijadikan sampel penelitian dapat fokus pada satu kelompok UMKM (kelompok UMKM menengah, kecil, atau mikro saja), karena masing-masing kelompok memiliki karakteristik yang cukup berbeda.

\section{DAFTAR PUSTAKA}

A Research Note on The Theory of SME : Bank Relationship. Small Business Economic, Vol 10

Baas, Timo dan Mechthild Schrooten. 2006. Relationship Banking and SMEs : A Theoretical Analysis. Vol 27.

Basri, Yuswar Zainul dan Mahendro Nugroho. 2009. Ekonomi Kerakyatan : Usaha Mikro, Kecil, dan Menengah. Jakarta: Penerbit Universitas Trisakti Bank Mandiri.

Cooper, Donald R. \& Schindler, Pamela S. 2006. Metode Riset Bisnis. Volume 1.Edisi 9.Terjemahan.PT. Media Global Edukasi. Jakarta.
Cziraky, D., S. Tisma and A. Pisarovic 2005. Determinants of the Low SME Loan Approval Rate in Croatia, Small Business Economics, 25, 347-372.

Emiliawati, Evi. 2011. Persepsi Para Pelaku UKM (Usaha Kecil Dan Menengah) Terhadap Penerapan Akuntansi. Rangkuman Skripsi. STIE Perbanas. Surabaya.

Ghozali, Imam. 2009. Aplikasi Analisis Multivariate dengan Program SPSS. Semarang : Universitas Diponegoro.

Harahap, Sofyan Safri. 2000. Teori Akuntansi. Rajawali Pers. Jakarta

Harahap, Sofyan, Syafri, Wiroso, \& Yusuf, Muhammad 2010, Akuntansi Perbankan Syariah (edisi 4) Jakarta: Penerbit LPFE Usakti.

http://fedepkotamagelang.com/index.php/ berita/34-sosialisasi-nama-baru-fedepkota-magelang.

http://tri-bowop.blogspot.com/2012/01/teoriakuntansi-sak-etap.html.

Idrus. 2000. Akuntansi dan Pengusaha Kecil. Akuntansi.Edisi 07/Maret/Th. VII.

Ikatan Akuntan Indonesia. 2009. Standar Akuntansi Keuangan Entitas Tanpa Akuntabilitas Publik. Jakarta. Penerbit: Dewan Standar Keuangan Ikatan Akuntansi Indonesia.

Indonesia Small Business Research Center. 2003. Usaha Kecil Indonesia: Tinjauan Tahun 2002 dan Praspek Tahun 2003. LP3EKadin Indonesia. Jakarta.

International Accounting Standards Board. 2004. Discussion Paper: Preliminaly Views on Accounting Standards for Small and Medium-sized Etities. IASB. London. United Kingdom.

Jati, Hironnymus, Bala, Beatus, dan Otnil Nisnoni. 2004. Menumbuhkan Kebiasaan Usaha Kecil Menyusun Laporan Keuangan. Jurnal Bisnis dan Usahawan, II No. 8, 210-218. 
Kreitner, R., and A. Kinicki. 2001. Organizational Behavior. Fifth Ed. Irwin McGraw-Hill. Boston.

Khan, A. 2006. Keterkaitan Ekonomi Dan Ekologi. CTRC. Bogor

Megginson, W.L., M.J. Byrd, and L.C. Megginson. 2000. Small Business Management: An Entrepreneur's Guidebook. Third Ed. Irwin McGraw-Hill. Boston.

Maryanto, Singgih. 2006. Pengaruh Persepsi Keadilan Terhadap Komitmen Organisasi Dan Keinginan Karyawan Untuk Keluar Dari Organisasi. Telaah Bisnis, Vol. 7 No. 1: 29-47.

Murniati. 2002. Analisis Faktor-Faktor yang Mempengaruhi Penyiapan dan Penggunaan Informasi Akuntansi pada Pengusaha Kecil dan Menengah di Jawa Tengah.Semarang : Universitas Diponegoro.

Pinasti, M. 2001. Penggunaan Informasi Akuntansi dalam Pengelolaan Usaha Para Pedagang Kecil di Pasar Tradisional Kabupaten Banyumas.Jurnal Ekonomi, Bisnis, dan Akuntansi, No 1 Vol 3. ,. 2007. Pengaruh Penyelenggaraan Dan Penggunaan Informasi Akuntansi Terhadap Persepsi Pengusaha Kecil Atas Informasi Akuntansi: Suatu Riset Eksperimen. SNA $X$. Unhas Makasar. 26-28 Juli.

Rudiantoro, R., Veronica Siregar, Sylvia. 2011. Kualitas Laporan Keuangan Umkm Serta Prospek Implementasi SAK ETAP. SNA XIV. Banda Aceh. 21-22 Juli.
Said, Adri \& N. Ika Widjaja, 2007. Akses Keuangan UMKM: Buku Panduan untuk Membangun Akses Pembiayaan bagi Usaha Menengah, Kecil dan Mikro dalam Konteks Pembangunan Daerah. Konrad Adenauer Stiftung.

Schiffman, Leon G dan Leslie L Kanuk. 2010. Consumer Behavior.New Jearsey: Pearson Education, Inc.

Siregar, Sylvia Veronica, S Nurwahyu Harahap, dan Wasilah. 2011. Evaluasi Tantangan Penerapan Standar Akuntansi Entitas Tanpa Akuntabilitas Publik (SAK ETAP) untuk Usaha Kecil dan Menengah. Proposal Hibah RUUI.

Sugiyono. 2007. Metode Penelitian Bisnis. Bandung : CV Alfabeta

Suwardjono. 2005. Teori Akuntansi: Perekayasaan Pelaporan Keuangan. Yogyakarta: BPFE

Triyuwono, Iwan, 2006. Akuntansi Syariah, PT Raja Grafindo Persada

Wahdini dan Suhairi.2006. Persepsi Akuntan Terhadap Overload Standar Akuntansi Keuangan (SAK) Bagi Usaha Kecil Dan Menengah. SNA IX-Padang.

Warsono, Sony dan Endra Murti. 2010. Akuntansi UMKM Ternyata Mudah Dipahami dan Dipraktikkan.Yogyakarta : Asgard Chapter Winarno. Zimele, Angelo. (2009). The SMME Business Toolkit. New York: SBDA(Pty)Ltd. 


\section{LAMPIRAN}

\section{Definisi Operasional dan Pengukuran Variabel}

\begin{tabular}{|c|c|c|}
\hline $\begin{array}{c}\text { Nama } \\
\text { Variabel }\end{array}$ & Definisi & Pengukuran \\
\hline $\begin{array}{l}\text { Jenis } \\
\text { Kelamin } \\
(\mathrm{JK})\end{array}$ & $\begin{array}{l}\text { Jenis kelamin dari } \\
\text { pemilik/manajer } \\
\text { UMKM }\end{array}$ & $\begin{array}{l}\text { Variabel ini merupakan dummy } \\
\text { variabel: } \\
\text { 1. Pria } \\
\text { 2. Wanita }\end{array}$ \\
\hline $\begin{array}{l}\text { Pendidikan } \\
\text { Terakhir } \\
\text { (PT) }\end{array}$ & $\begin{array}{l}\text { Tingkat pendidikan } \\
\text { tertinggi } \\
\text { manajer/pemilik } \\
\text { UMKM }\end{array}$ & $\begin{array}{l}\text { Variabel ini merupakan dummy } \\
\text { variabel: } \\
\text { 1. SD/SMP } \\
\text { 2. SMA } \\
\text { 3. S1 }\end{array}$ \\
\hline $\begin{array}{l}\text { Latar } \\
\text { belakang } \\
\text { pendidikan } \\
\text { (LB) }\end{array}$ & $\begin{array}{l}\text { Jurusan pendidikan } \\
\text { terakhir yang } \\
\text { ditempuh responden }\end{array}$ & $\begin{array}{l}\text { Variabel ini merupakan dummy } \\
\text { variabel: } \\
\text { 1. Ekonomi, akuntansi atau } \\
\quad \text { manajemen } \\
\text { 2. Lainnya }\end{array}$ \\
\hline $\begin{array}{l}\text { Ukuran } \\
\text { usaha (SZ) }\end{array}$ & $\begin{array}{l}\text { Besarnya kekayaan } \\
\text { dan hasil penjualan } \\
\text { tahunan }\end{array}$ & 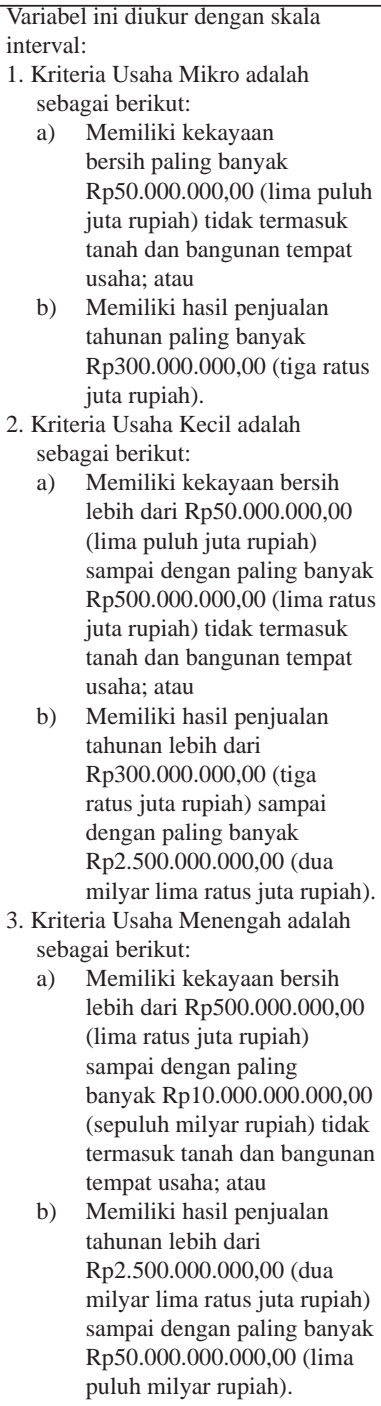 \\
\hline $\begin{array}{l}\text { Lama Usaha } \\
\text { berdiri (LU) }\end{array}$ & $\begin{array}{l}\text { Jumlah tahun } \\
\text { yangdihitung dari } \\
\text { awalpendirian } \\
\text { perusahaansampai } \\
\text { sekarang }\end{array}$ & $\begin{array}{l}\text { Variabel ini diukur dengan skala } \\
\text { interval: } \\
\text { 1. }<5 \text { tahun } \\
\text { 2. } 5-10 \text { tahun } \\
\text { 3. }>10 \text { tahun }\end{array}$ \\
\hline
\end{tabular}

\begin{tabular}{|c|c|c|}
\hline $\begin{array}{c}\text { Nama } \\
\text { Variabel }\end{array}$ & Definisi & Pengukuran \\
\hline $\begin{array}{l}\text { Pangsa Pasar } \\
\text { (PP) }\end{array}$ & & $\begin{array}{ll}\text { a. } & \text { Local } \\
\text { b. } & \text { Regional } \\
\text { c. } & \text { Nasional } \\
\text { d. } & \text { Internasional }\end{array}$ \\
\hline $\begin{array}{l}\text { Kualitas } \\
\text { laporan } \\
\text { keuangan } \\
(\mathrm{KW})\end{array}$ & & Indeks Kualitas laporan keuangan \\
\hline $\begin{array}{l}\text { Jumlah } \\
\text { kredit yang } \\
\text { diajukan } \\
(\mathrm{CR})\end{array}$ & $\begin{array}{l}\text { Besarnya nominal } \\
\text { rupiah kredit yang } \\
\text { diajukan }\end{array}$ & $\begin{array}{l}\text { Variabel ini diukur dengan skala } \\
\text { interval dandikategorisasi: } \\
\text { 1. Kurang dari Rp } 10.000 .000,- \\
\text { 2. Rp } 10.000 .001,- \text { s/d Rp } \\
\text { 25.000.000,- } \\
\text { 3. Rp } 25.000 .001,- \text { s/d Rp } \\
50.000 .000,- \\
\text { 4. Rp 50.000.001,- s/d } \\
\text { Rp100.000.000,- } \\
\text { 5. Lebih dari Rp } 100.000 .000,-\end{array}$ \\
\hline $\begin{array}{l}\text { Jangka } \\
\text { waktu kredit } \\
(\mathrm{TK})\end{array}$ & Lama angsuran & $\begin{array}{l}\text { Variabel ini diukur dengan skala rasio } \\
\text { yaitu dalam bentuk berapa bulan } \\
\text { angsuran }\end{array}$ \\
\hline $\begin{array}{l}\text { Tingkat } \\
\text { informasi } \\
\text { dan } \\
\text { sosialisasi } \\
\text { yang } \\
\text { diterima oleh } \\
\text { pengusaha } \\
\text { (IS) }\end{array}$ & $\begin{array}{l}\text { Sumber informasi } \\
\text { terkait SAK ETAP }\end{array}$ & $\begin{array}{l}\text { Variabel ini merupakan dummy } \\
\text { variabel: } \\
\text { a. Seminar/Pelatihan; } \\
\text { b. Internet; } \\
\text { c. Buletin/Majalah; } \\
\text { d. Lainnya (sebutkan)___ }\end{array}$ \\
\hline $\begin{array}{l}\text { Omzet } \\
\text { UMKM } \\
(\mathrm{OZ})\end{array}$ & $\begin{array}{l}\text { Besarnya omzet } \\
\text { UMKM dalamsatu } \\
\text { tahun }\end{array}$ & $\begin{array}{l}\text { Variabel ini diukur dengan skala } \\
\text { interval dandikategorisasi: } \\
\text { 1. } \quad \text { <dari Rp100 juta; } \\
\text { 2. } \quad \text { Rp100 juta - Rp } 499 \text { juta; } \\
\text { 3. } \quad \text { Rp500 juta - Rp } 2.5 \text { miliar; } \\
\text { 4. } \quad \text { >dari Rp2.5 miliar }\end{array}$ \\
\hline $\begin{array}{l}\text { Persepsi } \\
\text { pengusaha } \\
\text { terkait } \\
\text { pentingnya } \\
\text { pelaporan } \\
\text { keuangan } \\
\text { (PS) }\end{array}$ & $\begin{array}{l}\text { Seberapa pentingkah } \\
\text { laporan keuangan } \\
\text { bagi tumbuh dan } \\
\text { berkembangnya } \\
\text { perusahaan }\end{array}$ & $\begin{array}{l}\text { Variabel ini diukur dengan skala } \\
\text { likert } \\
(1-4) \\
\text { 1. Sangat tidak penting } \\
\text { 2. Tidak penting } \\
\text { 3. Penting } \\
\text { 4. Sangat Penting }\end{array}$ \\
\hline $\begin{array}{l}\text { Jumlah } \\
\text { kredit yang } \\
\text { diterima } \\
\text { (CA) }\end{array}$ & $\begin{array}{l}\text { Besarnya nominal } \\
\text { rupiah kredit yang } \\
\text { disetujui pihak bank }\end{array}$ & $\begin{array}{l}\text { Variabel ini diukur dengan skala } \\
\text { interval dandikategorisasi: } \\
\text { 1. Kurang dari Rp } 10.000 .000,- \\
\text { 2. Rp } 10.000 .001,- \text { s/d Rp } \\
\text { 25.000.000,- } \\
\text { 3. Rp 25.000.001,- s/d Rp } \\
\text { 50.000.000,- } \\
\text { 4. Rp 50.000.001,- s/d } \\
\text { Rp100.000.000,- } \\
\text { 5. Lebih dari Rp } 100.000 .000,-\end{array}$ \\
\hline $\begin{array}{l}\text { Besarnya } \\
\text { pemahaman } \\
\text { pengusaha } \\
\text { UMKM } \\
\text { terkait SAK } \\
\text { ETAP (UN) }\end{array}$ & $\begin{array}{l}\text { Kegiatan akuntansi } \\
\text { yang dilakukan oleh } \\
\text { UKM }\end{array}$ & $\begin{array}{l}\text { Variabel ini diukur dengan skala } \\
\text { likert } \\
(1-4) \\
\text { 1. Sangat tidak paham } \\
\text { 2. Tidak paham } \\
\text { 3. Paham } \\
\text { 4. Sangat Paham }\end{array}$ \\
\hline
\end{tabular}




\section{Model Penelitian}
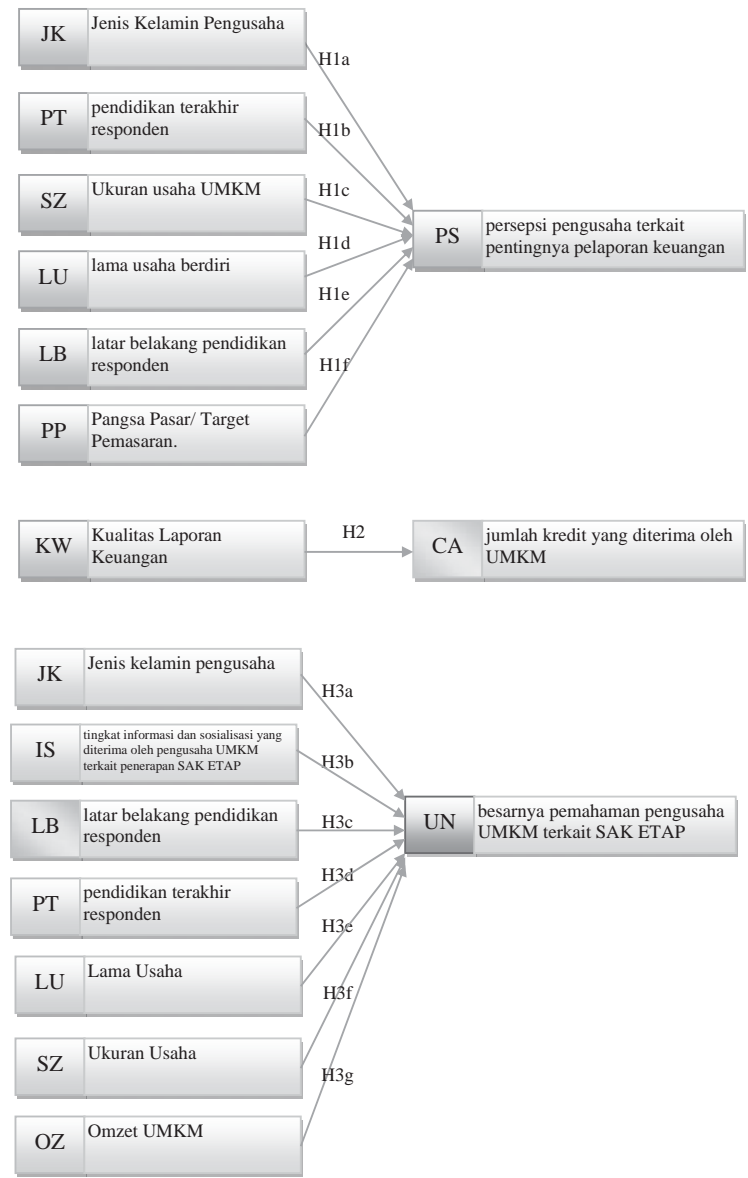